\title{
ANALISIS PENYIMPANGAN DALAM PELAKSANAAN PROSEDUR PEMBERIAN KREDIT DAN PENERAPAN KEBIJAKAN PEMERINTAH TERHADAP PIUTANG TAK TERTAGIH (PADA PT. BPR PRIMA MULIA ANUGRAH CABANG PADANG)
}

\author{
Tia Yunita Sari, Renil Septiano \\ Akuntansi, STIE-KBP PADANG \\ Email: Tiayunitasari96@gmail.com \\ renil.septiano@akbpstie.ac.id
}

\begin{abstract}
The purpose of this study is to empirically test the deviations in the implementation of crediting procedures and the implementation of government policies affect the bad debts. The population in this research is credit customers of PT. BPR Prima Mulia Anugrah Padang Branch with Samples of 63 people using Slovin formula. Required data is obtained through questionnaires. Data analysis technique used is with Multiple Linear Regression Analysis. The result of the research shows that the irregularities in the implementation of crediting procedures has a significant positive effect on bad debts, the implementation of government policy has a significant positive effect on bad debts, the irregularities in the implementation of lending procedures and the implementation of government policies have a significant positive effect simultaneously on bad debts.
\end{abstract}

Keywords : irregularities in the implementation of crediting procedures; implementation of government policy; bad debts.

\section{PENDAHULUAN}

Bank Perkreditan Rakyat (BPR) ialah salah satu dari lembaga yang menyediakan jasa kredit. BPR menghimpun dana melalui simpanan yang berbentuk tabungan, deposito berjangka dan bentuk lainnya serta menyalurkan dana dalam bentuk kredit kepada masyarakat. Pinjaman yang diberikan merupakan piutang usaha bagi BPR yang harus ditagih ketika jatuh tempo. Sesuai perkembangannya tidak semua piutang dapat ditagih dengan lancar Menurut Jusup dalam Lutfi Arrum Sari (2015) piutang tak tertagih merupal piutang yang menyebabkan kerugian bagi perusahaan karena nasabah tic dapat melunasi atau tidak bisa melaksanakan kewajibannya. Ketidakmampuan nasabah tersebut bisa terjadi karena adanya penyebab. Menurut Abdul dalam Veralita \& Khairani (2014) faktor-faktor yang menjadi penyebab piutang tak tertagih adalah faktor internal dan faktor eksternal. Faktor internal berasal dari pihak perusahaan seperti terjadinya kerjasama antara analis dengan calon debitur dalam memperoleh pinjaman kredit, persyaratan dan prosedur kredit yang 
mudah atau pihak analis kurang ahli dalam perhitungan. faktor eksternal ialah factor yang berasal dari pihak debitur baik yang disengajanya maupun yang tidak disengaja. Unsur kesengajaan seperti membuat berbagai alasan, salah satunya menjadikan kebijakan atau peraturan pemerintah tentang kredit atau kenaikan harga BBM menjadi alasan untuk menunda-nunda pembayaran hutang serta memiliki tujuan untuk tidak akan melunasi hutangnya dan unsur ketidaksengajaan seperti musibah yang dialami debitur.

Resiko tersebut telah dialami oleh PT. BPR Prima Mulia Anugrah Cabang Padang. Pada tahun 2013, dilaporkan jumlah pinjaman yang diberikan sebesar Rp. 3.161.460.000,- kepada 242 debitur dan mengalami piutang tak tertagih sebesar Rp85.692.587,-. Pada tahun 2014, jumlah kredit yang diberikan meningkat menjadi Rp3.605.912.000,- kepada 282 debitur dan jumlah piutang tak tertagih meningkat menjadi Rp191.883.076,. Sedangkan pada tahun 2015, jumlah kredit yang diberikan sebesar Rp3.798.833.637 kepada 238 debitur dan jumlah piutang tak tertagih juga mengalami peningkatan menjadi Rp472.715.736.

Beberapa riset terdahulu mengenai piutang tak tertagih telah dilakukan, diantaranya adalah penelitian Veralita \& Khairani (2014) menunjukkan bahwa faktor internal (lemahnya sistem informasi kredit dan penyimpangan dalam pelaksanaan prosedur pemberian kredit) dan faktor eksternal (penurunan kegiatan ekonomi dan kegagalan usaha debitur) berpengaruh signifikan positif terhadap piutang tak tertagih. Sementara itu, faktor internal (lemahnya sistem administrasi dan pengawasan) dan faktor eksternal (debitur mengalami musibah) tidak berpengaruh signifikan positif terhadap piutang tak tertagih.

Penelitian Lutfi Arrum Sari (2015) menunjukkan bahwa faktor-faktor yang menjadi penyebab piutang tak tertagih pada PT. PELINDO III Cabang Tanjung Emas Semarang yaitu berasal dari pihak internal dan pihak eksternal. Pihak internal seperti piutang lama yang belum diberlakukannya uang panjar, lemahnya pengendalian internal terhadap piutang tak tertagih, kurang memadainya jumlah eksekutif atau staf bagian piutang, watak buruk pengguna jasa, kegagalan debitur pada bidang usahanya atau penurunan kondisi ekonomi perusahaan. Sedangkan faktor-faktor yang ditimbulkan oleh pihak eksternal yaitu kebijakan pemerintah, perkembangan teknologi dan bencana alam.

Penelitian Algumeri (2013) menunjukkan bahwa kebijakan pemerintah, bencana alam, penyimpangan pemberian kredit, pendapatan dan pengeluaran pemanfaat yang tidak menentu, itikad baik nasabah dan penyalahgunaan dana yang telah diberikan menjadi faktor yang menyebabkan terjadinya kredit macet dan penelitian Yulianto (2011) juga menunjukan terdapatnya pengaruh antara faktor internal (aspek pemasaran, aspek pengaturan keuangan, aspek dana, aspek teknis, dan aspek manajemen) dan faktor eksternal (perkembangan teknologi dan kebijakan pemerintah) terhadap kredit macet pada PD. BPR BKK Wonosobo. 
Berdasarkan latar belakang masalah diatas dan hasil penelitian terdahulu penulis tertarik untuk meneliti kembali tentang piutang tak tertartagih dengan judul "Analisis Penyimpangan Dalam Pelaksanaan Prosedur Pemberian Kredit dan Penerapan Kebijakan Pemerintah Terhadap Piutang Tak Tertagih Pada PT.BPR Prima Mulia Anugrah Cabang Padang”.

\section{TINJAUAN PUSTAKA}

\section{Piutang Tak Tertagih}

Piutang tak tertagih menurut Jusup dalam Lutfi Arrum Sari (2015) adalah piutang yang dapat menimbulkan kerugian bagi perusahaan karena debitur tidak ingin atau tidak mampu melaksanakan kewajibanya. Keiso dan Weygant dalam Veralita \& Khairani (2014) menyatakan bahwa piutang tak tertagih merupakan penurunan aktiva piutang usaha, penurunan yang berkaitan dengan laba atau ekuitas saham atau kerugian atas pendapatan yang diperoleh.

Kategori piutang tak tertagih menurut Soemarso dalam Veralita \& Khairani (2014) adalah :

1. Kredit dalam perhatian khusus

Kriterianya :

a. Terdapat tunggakan pembiayaan pokok atau bunga sampai 90 hari.

b. Jarang mengurangi cerungan atau overhead.

c. Hubungan antara nasabah dengan perusahaan berjalan baik dan informasi keuangan debitur selalu disampaikan secara teratur dan akurat.

d. Dokumen kredit lengkap dan pengikat angunan kuat.

e. Pelanggaran perjanjian kredit yang tidak prinsipil.

2. Kredit Kurang Lancar

\section{Kriterianya :}

a. Tunggakan pembayaran pokok atau bunga yang telah melampaui 90 hari sampai dengan 120 hari.

b. Terdapat cerukan yang berulang kali khususnya untuk menutupi kerugian operasional dan kekurangan arus kas.

c. Hubungan nasabah dengan perusahaan buruk dan informasi keuangan debitur tidak dapat dipercaya.

d. Dokumentasi kredit kurang lengkap dan pengikatan angunan yang lemah.

e. Pelanggaran terhadap persyaratan pokok kredit.

f. Perpanjangan kredit untuk menyembunyikan kesulitan keuangan.

3. Kredit Diragukan

Kriterianya :

a. Tunggakan pembayaran pokok dan bunga yang telah melampaui 121 hari sampai dengan 180 hari.

b. Terjadi cerukan yang sifatnya permanen khususnya untuk menutupi kerugian operasional dan kekurangan arus kas.

c. Hubungan antara nasabah dengan perusahaan sudah tidak baik dan informasi keuangan debitur sudah tidak tersedia atau tidak dapat dipercaya. 
4. Kredit Macet

d. Dokumentasi kredit tidak lengkap dan pengikat angunan yang lemah.

e. Pelanggaran yang prinsipil terhadap persyaratan pokok dalam perjanjian kredit.

Kriterianya :

a. Tunggakan pembayaran pokok dan bunga telah melampaui 180 hari.

b. Dokumentasi kredit atau pengikatan angunan tidak ada.

\section{Penyimpangan Dalam Pelaksanaan Prosedur Pemberian Kredit}

Menurut J Paul B. Horton dalam Ainni (2010) penyimpangan ialah bentuk perilaku yang dilakukan oleh seseorang yang tidak sesuai dengan norma yang berlaku dalam kelompok atau masyarakat. Sedangkan prosedur menurut Lapoliwa dalam Asmawati (2011) merupakan urutan pekerjaan yang melibatkan beberapa orang dalam satu atau lebih bagian organisasi untuk menjamin adanya keseragaman dalam penanganan transaksi yang berulangulang.

Menurut Rivai Veihzal dalam Asmawati (2011) kredit berasal dari bahasa latin yaitu "credo" yang artinya percaya. Maksudnya adalah pihak penyedia jasa kredit mempercayai orang yang menerima jasa tersebut bahwa kredit yang diberikan akan dikembalikannya sesuai dengan perjanjian dan si penerima kredit tersebut memiliki kewajiban untuk membayarkan kembali pinjaman tersebut sesuai jangka waktu yang telah ditetapkan.

Menurut Horne dan Wachowicz dalam Kurniawan Syaputera \& Khairani (2013) prosedur dalam pemberian kredit ada 3 yaitu:

1. Mendapatkan informasi tentang debitur agar debitur melengkapi syarat-syarat pemberian kredit dengan memperhatikan prinsip-prinsip $5 \mathrm{C}$.

2. Menganalisa data-data yang diperoleh untuk menentukan kelayakan pemohon apakah pantas atau tidak diberikan pinjaman atau kredit.

3. Membuat keputusan untuk menentukan besar kredit yang diberikan apakah jumlah kredit dapat diperbesar atau diperkecil dan menentukan batas tertinggi jumlah kredit yang dapat diberikan.

\section{Penerapan Kebijakan Pemerintah}

Menurut Siswanto dalam Muslim (2012) kredit bermasalah timbul karena adanya penyebab-penyebab yang membuat kemampuan debitur dalam mengembalikan kredit menurun, salah satu diantaranya adalah kebijakan pemerintah. Menurut Philipus M.Hadjon dalam Alfi Yunita (2016) kebijakan merupakan produk dari tata usaha negara yang bertujuan menampakkan keluar suatu kebijakan tertulis. Kebijakan dijadikan sebagai suatu aplikasi pencapaian tujuan, nilai-nilai dan praktik-praktik yang terarah. Kebijakan pemerintah atau kebijakan publik ialah tindakan-tindakan yang dikemukakan oleh individu, organisasi atau pemerintah dalam suatu lingkungan tertentu dengan cara menunjukkan hambatan-hambatan dan kesempatan-kesempatan dalam penerapan usulan kebijakan tersebut guna mencapai tujuan menurut Carl. J. 
Friedrick dalam Cawidu \& Cangara (2011). Menurut Sugiartono (2013) dalam perekonomian, pemerintah mengeluarkan kebijakan tentang kebijakan fiskal dan kebijakan moneter untuk mengatasi berbagai masalah yang dihadapi oleh negara. Kebijakan fiskal merupakan instrumen manajemen permintaan dengan upaya mempengaruhi tingkat aktifitas ekonomi melalui pengendalian pajak, subsidi dan pengeluaran pemerintah. Kebijakan ini dilaksanakan untuk membantu peningkatan pertumbuhan ekonomi dengan meningkatkan laju investasi, meningkatkan kesempatan kerja, meningkatkan stabilitas ekonomi, menanggulangi inflasi dan menigkatkan pendapatan nasional.

Namun pada kenyataannya, perubahan tarif pajak yang ditetapkan akan berpengaruh pada ekonomi masyarakat. Kenaikan tarif dasar listrik juga merupakan penerapan kebijakan fiskal oleh pemerintah dengan menurunkan nilai subsidi. Hal ini membuat masyarakat semakin sulit menjalankan aktifitas usahanya atau aktifitas sehari-hari. Kenaikan ini berdampak pada masyarakat yang memerlukan listrik untuk aktifitas usaha atau untuk konsumsi. Kenaikan tarif listrik membuat pendapatan atau penghasilan masyarakat menjadi berkurang. Sementara itu, kebijakan moneter merupakan kebijakan pemerintah yang berlandaskan pada hubungan antara suku bunga dalam perekonomian dengan jumlah uang yang beredar yang pada akhirnya akan mempengaruhi ekonomi masyarakat.

Kebijakan pemerintah mengenai fiskal, moneter atau kebijakan lainnya yang diterbitkan departemen tertentu secara langsung maupun tidak langsung bisa mempengaruhi suatu kelompok usaha, salah satu diantaranya adalah BPR. Semakin banyak peraturan pemerintah yang dikeluarkan akan semakin berpengaruh terhadap aktifitas usaha BPR serta berdampak pada kondisi kredit macet dari BPR tersebut. Menurut Suyatno dalam Yulianto, (2011) kebijakan pemerintah dapat diukur dengan kebijakan pajak, peraturan pemerintah tentang kredit, kebijakan tarif dasar listrik.

\section{Hipotesis}

Ditarik hipotesis untuk penelitian ini sebagai berikut :

$\mathrm{H}_{1}$ : Penyimpangan dalam pelaksanaan prosedur pemberian kredit berpengaruh positif dan signifikan terhadap piutang tak tertagih.

$\mathrm{H}_{2}$ : Penerapan kebijakan pemerintah berpengaruh positif dan signifikan terhadap piutang tak tertagih.

\section{Kerangka konseptual}

Berdasarkan hipotesis diatas maka dapat digambarkan kerangka konseptual penelitian ini sebagai berikut :

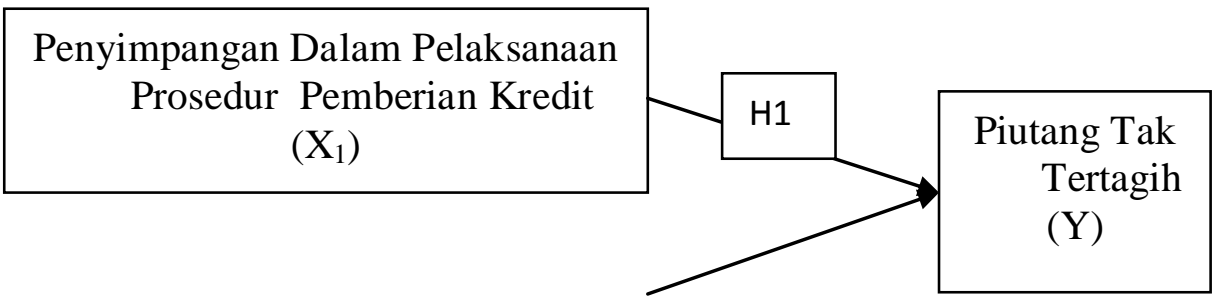


\begin{tabular}{|c|c|}
\cline { 2 - 3 } & $\begin{array}{c}\text { Penerapan Kebijakan Pemerintah } \\
\left(\mathrm{X}_{2}\right)\end{array}$ \\
$\mathrm{HETOD}$ & $\mathrm{H} 2$ \\
\hline
\end{tabular}

Jenis penelitian yang digunakan dalam penelitian adalah pendekatan kuantitatif. Penelitian dilakukan pada PT.BPR Prima Mulia Anugrah Cabang Padang. Populasi dalam penelitian adalah adalah seluruh nasabah kredit PT. BPR Prima Mulia Anugrah Cabang Padang yang berjumlah 172 orang dengan sampel sebanyak 63 orang dengan menggunakan rumus Slovin. Jenis data adalah interval dan sumber data yang digunakan adalah data primer dan data sekunder. Data primer didapat dengan cara membagikan kuesioner bagi debitur dan data sekunder diperoleh langsung dari PT. BPR Prima Mulia Anugrah Cabang Padang.

Metode pengumpulan data pada penelitian ini melalui kuesioner. Pengujian dalam penelitian ini yaitu menggunakan analisis deskriptif, uji validitas, uji reabilitas, uji asumsi klasik, analisis regresi linear berganda, uji signifikansi individual (uji $\mathrm{T}$ ), uji $\mathrm{F}$ dan uji $\mathrm{R}^{2}$. Defenisi operasional variabel bertujuan untuk mendapatkan suatu alat ukur yang sesuai dengan hakikat variabel yang diteliti. Berikut defenisi operasional variabel dalam penelitian ini :

Defenisi Operasional Variabel

\begin{tabular}{|c|c|c|c|}
\hline Variabel & Konsep & Indikator & Instrumen \\
\hline $\begin{array}{l}\text { Piutang Tak } \\
\text { Tertagih } \\
\text { (Y) }\end{array}$ & $\begin{array}{l}\text { Resiko kerugian } \\
\text { piutang yang } \\
\text { tidak dapat } \\
\text { terbayar oleh } \\
\text { debitur karena } \\
\text { berbagai alasan }\end{array}$ & $\begin{array}{l}\text { Menurut Haninun, (2011) } \\
\text { piutang tak tertagih dapat } \\
\text { diukur dengan : } \\
\text { 1. Kredit dalam perhatian } \\
\text { khusus } \\
\text { 2. Kredit kurang lancar } \\
\text { 3. Kredit diragukan } \\
\text { 4. Kredit macet }\end{array}$ & $\begin{array}{l}\text { Kuesioner } \\
\text { (No. 7-10) }\end{array}$ \\
\hline $\begin{array}{l}\text { Penyimpang } \\
\text { an dalam } \\
\text { pelaksanaan } \\
\text { Prosedur } \\
\text { Pemberian } \\
\text { (X1) }\end{array}$ & $\begin{array}{l}\text { Perbedaan } \\
\text { pelaksanaan } \\
\text { Analisis kredit, } \\
\text { kebijakan } \\
\text { pemberian } \\
\text { kredit, } \\
\text { rekomendasi } \\
\text { dari bank }\end{array}$ & $\begin{array}{l}\text { Horne dan Wachowicz } \\
\text { dalam Kurniawan Syaputera } \\
\& \text { Khairani (2013) prosedur } \\
\text { dalam pemberian kredit } \\
\text { adalah: } \\
\text { 1. Pengajuan berkas-berkas } \\
\quad \text { kredit } \\
\text { 2. Analisa data-data } \\
\text { 3. Keputusan kredit }\end{array}$ & $\begin{array}{l}\text { Kuesioner } \\
\text { (No. 1-3) }\end{array}$ \\
\hline $\begin{array}{l}\text { Penerapan } \\
\text { Kebijakan } \\
\text { Pemerintah } \\
\text { (X2) }\end{array}$ & $\begin{array}{l}\text { Kebijakan- } \\
\text { kebijakan yang } \\
\text { dikembangkan } \\
\text { oleh pejabat- } \\
\text { pejabat dan } \\
\text { badan-badan } \\
\text { pemerintah }\end{array}$ & $\begin{array}{l}\text { Menurut } \\
\text { Yulianto, (2011) indikator } \\
\text { kebijakan } \\
\text { diantaranya : } \\
\text { 1. Kebijakan pajak } \\
\text { 2. Peraturan pemerintah } \\
\text { 3. Kebijakan tarif dasar listrik }\end{array}$ & $\begin{array}{l}\text { Kuesioner } \\
\text { (No. 4-6) }\end{array}$ \\
\hline
\end{tabular}




\section{HASIL DAN PEMBAHASAN}

\section{Analisis Deskriptif}

Berdasarkan pengujian statistik yang telah dilakukan diperoleh ringkasan hasil pengelolaan data secara deskriptif 63 sampel seperti yang terlihat pada tabel dibawah ini :

Statistik Deskriptif Variabel Penelitian

\begin{tabular}{|l|r|r|r|r|r|}
\hline & N & Minimum & Maximum & Mean & $\begin{array}{c}\text { Std. } \\
\text { Deviation }\end{array}$ \\
\hline PDPPPK & 63 & 3 & 10 & 6,08 & 1,406 \\
PKP & 63 & 3 & 11 & 5,27 & 1,780 \\
PTT & 63 & 5 & 16 & 8,41 & 2,137 \\
Valid N (listwise) & 63 & & & & \\
\hline
\end{tabular}

Sumber : data olahan SPSS 23, (2017)

Dari tabel diatas dapat terlihat bahwa tingkat penyimpangan dalam pelaksanaan prosedur pemberian kredit terendah adalah sebesar 3, tingkat tertingginya sebesar 10, tingkat rata-rata 6,08 dengan standar deviasi 1,406. Tingkat terendah penerapan kebijakan pemerintah adalah 3, tingkat tertingginya yaitu sebesar 11, tingkat rata-rata sebesar 5,27 dengan standar deviasi 1,780. Sedangkan tingkat terendah untuk variabel piutang tak tertagih adalah 5, tingkat tertingginya sebesar 16, tingkat rata-rata 8,41 dengan standar deviasi sebesar 2,137 .

\section{Uji Validitas Dan Reliabilitas}

Uji validitas dilakukan kepada 63 data dengan cara mengkorelasikan skor item instrumen pervariabel. Instrumen dikatakan valid apabila corrected itemtotal correlation lebih besar dari 0,3. Sedangkan reliabilitas suatu instrumen dikatakan baik jika memiliki nilai Cronbach's Alpha-nya diatas 0,6.

Hasil Uji Validitas

\begin{tabular}{|l|c|c|c|}
\hline \multicolumn{1}{|c|}{ Variabel } & Item & $\begin{array}{c}\text { Corrected Item-Total } \\
\text { Correlation }\end{array}$ & Ket \\
\hline $\begin{array}{l}\text { Penyimpangan Dalam } \\
\text { Pelaksanaan Prosedur } \\
\text { Pemberian Kredit (X1) }\end{array}$ & PDPPPK.1 & 0,371 & Valid \\
\cline { 2 - 4 } & PDPPPK.2 & 0,501 & Valid \\
\cline { 2 - 4 } $\begin{array}{l}\text { Penerapan Kebijakan } \\
\text { Pemerintah (X2) }\end{array}$ & PDPPPK.3 & 0,393 & Valid \\
\cline { 2 - 4 } & PKP.1 & 0,611 & Valid \\
\cline { 2 - 4 } & PKP.2 & 0,405 & Valid \\
\hline Piutang Tak Tertagih (Y) & PTT.1 & 0,672 & Valid \\
\cline { 2 - 4 } & PTT.2 & 0,432 & Valid \\
\cline { 2 - 4 } & PTT.3 & 0,475 & Valid \\
\cline { 2 - 4 } & PTT.4 & 0,509 & Valid \\
\hline
\end{tabular}

Sumber : data olahan SPSS 23, (2017) 
Hasil Uji Reliabilitas

\begin{tabular}{|l|c|c|}
\hline \multicolumn{1}{|c|}{ Variabel } & Cronbach's Alpha & Keterangan \\
\hline PDPPPK & 0,602 & Reliabel \\
\hline PKP & 0,729 & Reliabel \\
\hline PTT & 0,693 & Reliabel \\
\hline
\end{tabular}

Sumber : data olahan SPSS 23, (2017)

Dari tabel hasil uji validitas dan uji reliabilitas diketahui bahwa semua butir instrumen dari variabel-variabel yang diuji menunjukan valid dan reliabel.

\section{Uji Asumsi Klasik}

\section{a. Uji Normalitas}

Pengujian yang digunakan adalah kolmogorov-Smirnov atau subjek dengan taraf signifikan $(\alpha) 0,05$ apabila nilai $\mathrm{p}>\alpha$ maka terdistribusi normal atau sebaliknya. Berikut hasil uji normalitas menggunakan uji Kolmogoraf-Smirnov test sebagai berikut:

Uji Normalitas

One-Sample Kolmogorov-Smirnov Test

\begin{tabular}{|ll|r|}
\hline & & \multicolumn{1}{c|}{$\begin{array}{c}\text { Standardized } \\
\text { Residual }\end{array}$} \\
\hline $\mathrm{N}$ & Mean & 63 \\
Normal Parameters & a,b &, 0000000 \\
Most Extreme Differences & Std. Deviation &, 98373875 \\
& Absolute &, 080 \\
& Positive &, 080 \\
Test Statistic & Negative &,- 049 \\
Asymp. Sig. (2-tailed) & &, 080 \\
\hline
\end{tabular}

a. Test distribution is Normal.

b. Calculated from data.

c. Lilliefors Significance Correction.

$\mathrm{d}$. This is a lower bound of the true significance.

Sumber : data olahan SPSS 23, (2017)

Berdasarkan tabel diatas, uji normalitas dengan pendekatan KolmogorovSmirnov Test dapat diketahui bahwa data terdistribusi normal. Hal ini dilihat melalui nilai Asymptotic Significance (2-tailed) sebesar 0, 200 ${ }^{\mathrm{c}, \mathrm{d}}$. Karena Significance lebih dari 0,050 maka residual terdistribusi secara normal.

\section{b. Uji Multikolineritas}

Untuk menunjukkan adanya multikolonieritas, nilai cut off yang digunakan adalah nilai tolerance $<0,10$ atau sama dengan nilai VIF $>10$. Berikut hasil uji multikolineritas : 
Hasil Uji Multikolinearitas

\begin{tabular}{|l|c|c|c|}
\hline \multicolumn{1}{|c|}{ Variabel } & Tolerance & VIF & Keterangan \\
\hline $\begin{array}{l}\text { Penyimpangan Dalam } \\
\text { Pelaksanaan Prosedur } \\
\text { Pemberian Kredit }\end{array}$ & 0,998 & 1,002 & $\begin{array}{c}\text { Tidak ada } \\
\text { multikolinieritas }\end{array}$ \\
\hline $\begin{array}{l}\text { Penerapan Kebijakan } \\
\text { Pemerintah }\end{array}$ & 0,998 & 1,002 & $\begin{array}{c}\text { Tidak ada } \\
\text { multikolinieritas }\end{array}$ \\
\hline
\end{tabular}

Sumber : data olahan SPSS 23, (2017)

Berdasarkan tabel diatas, nilai tolerance variabel penyimpangan dalam pelaksanaan prosedur pemberian kredit menunjukkan angka sebesar 0,998 dan nilai VIF-nya sebesar 1,002 atau VIF <10. Sementara nilai tolerance variabel penerapan kebijakan pemerintah menunjukkan angka sebesar 0,998 dan nilai VIF-nya juga sebesar $1,002<10$. Hal ini berarti bahwa dalam model regresi ini tidak terjadi multikolineritas karena nilai tolerance kedua variabel mendekati angka 1 dan nilai VIF tidak melebihi nilai cut off.

\section{c. Uji Heteroskedastisitas}

untuk menguji data apakah ada atau tidaknya masalah heteroskedastisitas pada penelitian ini digunakan uji glejser dengan menguji hubungan antara setiap variabel bebas terhadap nilai eror. Masalah heteroskedastisitas tidak terjadi jika nilai signifikansi antara variabel bebas dengan absolut residual lebih dari 0,05 dan sebaliknya jika nilai signifikansi antara variabel bebas dengan absolut residual kecil dari 0,05 berarti terjadi atau ada masalah heteroskedastisitas. Berikut hasil uji heterokedastisitas menggunakan Uji Glejser :

Hasil Uji Glejser

\begin{tabular}{|l|c|c|}
\hline Model & $\mathrm{T}$ & Sig. \\
\hline (Constant) &,- 315 &, 754 \\
PDPPPK & 1,903 &, 062 \\
PKP & 1,100 &, 276 \\
\hline
\end{tabular}

a. Dependent Variable: ABS_RES

Sumber : data olahan SPSS 23, (2017)

Berdasarkan tabel diatas, nilai signifikansi variabel penyimpangan dalam pelaksanaan prosedur pemberian kredit sebesar 0,062 dan nilai signifikansi variabel penerapan kebijakan penerintah sebesar 0,276 menunjukkan angka yang lebih besar dari nilai eror yaitu 0,05. Dapat disimpulkan bahwa tidak ada pengaruh antara variabel-variabel bebas terhadap variabel terikat dimana variabel terikat adalah error absolut $\left(\mathrm{e}_{\mathrm{i}}\right)$ serta menunjukkan tidak adanya gejala heteroskedastisitas. 


\section{Analisis Regresi Linear Berganda}

Hasil analisis regresi linear berganda pada penelitian ini dapat dilihat pada tabel dibawah :

\section{Hasil Uji Regresi Linear Berganda}

\begin{tabular}{|c|c|c|c|c|}
\hline \multirow{2}{*}{\multicolumn{2}{|c|}{ Model }} & \multicolumn{2}{|c|}{ Unstandardized Coefficients } & \multirow{2}{*}{$\begin{array}{c}\text { Standardized } \\
\text { Coefficients } \\
\text { Beta } \\
\end{array}$} \\
\hline & & $\mathrm{B}$ & Std. Error & \\
\hline 1 & (Constant) & 3,000 & 1,200 & \\
\hline & PDPPPK & ,396 & , 164 & ,261 \\
\hline & PKP & ,570 & , 129 & ,475 \\
\hline
\end{tabular}

a. Dependent Variable: PTT

Sumber : data olahan SPSS 23, (2017)

Berdasarkan tabel diatas, model regresi yang digunakan sebagai berikut :

$$
\mathrm{Y}=\text { 3,000 + 0,396 PDPPPK +0, 570 PKP + e }
$$

\section{Uji T}

Standar signifikansi uji $\mathrm{T}$ yang digunakan pada penelitian ini adalah 5\% atau 0,05. Hipotesis diterima jika nilai signifikannya dibawah 0,05 dan sebaliknya, jika nilai signifikan diatas 0,05 maka hipotesis ditolak. Hasil uji $\mathrm{T}$ dapat dilihat pada tabel berikut:

Hasil Uji T
Coefficients $^{\mathbf{a}}$
\begin{tabular}{|l|r|r|}
\hline Model & \multicolumn{1}{|l|}{ T } & \multicolumn{1}{|c|}{ Sig. } \\
\hline (Constant) & 2,499 &, 015 \\
PDPPPK & 2,420 &, 019 \\
PKP & 4,406 &, 000 \\
\hline
\end{tabular}

a. Dependent Variable: PTT

Sumber : data olahan SPSS 23, (2017)

Berdasarkan tabel diatas, ditarik kesimpulan bahwa hipotesis pertama dan hipotesis kedua diterima karena $\mathrm{T}$ hitung $>\mathrm{T}$ tabel. $\mathrm{T}$ hitung hipotesis pertama yaitu sebesar 2,420>T tabel sebesar 2,000 dan nilai $\mathrm{T}$ hitung hipotesis kedua sebesar 4,406>T tabel sebesar 2,000. T tabel diperoleh dengan menggunakan derajat kebebasan $(\mathrm{df})=63-3=60$ maka didapat $\mathrm{T}$ tabel sebesar 2,000. 


\section{Uji F}

Berikut hasil Uji F pada penelitian ini :

Hasil Uji F

\begin{tabular}{|l|c|c|}
\hline Model & F & Sig. \\
\hline $\begin{array}{l}\text { Regression } \\
\text { Residual } \\
\text { Total }\end{array}$ & 13,191 &, $000^{\mathrm{b}}$ \\
\hline
\end{tabular}

a. Dependent Variable: PTT

b. Predictors: (Constant), PKP, PDPPPK

Sumber : data olahan SPSS 23, (2017)

Berdasarkan tabel diatas, hasil Uji $\mathrm{F}$ menunjukkan nilai $\mathrm{F}$ hitung sebesar 62,255 dengan signifikansi 0,000 dan berpedoman pada df $1=\mathrm{k}-1=3-1=2$ dan $\mathrm{df} 2=\mathrm{n}-\mathrm{k}=63-3=60$ maka diperoleh $\mathrm{f}$ tabel sebesar 3,15. F hitung menunjukkan angka yang lebih besar dari $\mathrm{F}$ tabel yaitu 13,191>3,15. Dapat disimpulkan bahwa model regresi yang dipakai layak digunakan pada penelitian ini.

\section{Uji $\mathbf{R}^{2}$}

Jika nilai koefisien determinasi tersebut semakin mendekati angka 1 berarti hubungan antara variabel tersebut semakin erat. Berikut hasil uji $\mathrm{R}^{2}$ pada penelitian ini :

\begin{tabular}{l}
\multicolumn{5}{c}{$\begin{array}{c}\text { Hasil Uji } \mathbf{R}^{2} \\
\text { Model Summary }\end{array}$} \\
\begin{tabular}{|l|c|r|r|r|}
\hline Model & $\mathrm{R}$ & $\mathrm{R}^{2}$ & $\begin{array}{c}\text { Adjusted } \\
\mathrm{R}^{2}\end{array}$ & $\begin{array}{c}\text { Std. Error of the } \\
\text { Estimate }\end{array}$ \\
\hline 1 &, $553^{\mathrm{a}}$ &, 305 &, 282 & 1,811 \\
\hline
\end{tabular}
\end{tabular}

a. Predictors: (Constant), PKP, PDPPPK

b. Dependent Variable: PTT

Sumber : data olahan SPSS 23, (2017)

Dari tabel diatas, nilai $\mathrm{R}^{2}$ menunjukkan angka sebesar 0,305. Hal ini berarti bahwa piutang tak tertagih pada PT. BPR Prima Mulia Anugrah Cabang Padang dijelaskan oleh model ini sebesar 30,5\%. Sementara sisanya sebesar $69,5 \%$ merupakan variabel lain yang tidak dijelaskan dalam penelitian ini.

\section{PEMBAHASAN}

\section{Pengujian terhadap variabel penyimpangan dalam pelaksanaan prosedur pemberian kredit}

Berdasarkan hasil pengujian variabel penyimpangan dalam pelaksanaan prosedur pemberian kredit berpengaruh positif dan signifikan terhadap piutang tak tertagih dengan koefisien regresi sebesar 0,396 dan hasil uji T menunjukkan nilai signifikan sebesar $0,019<0,05$. Hal ini berarti bahwa variabel 
penyimpangan dalam pelaksanaan prosedur pemberian kredit berpengaruh terhadap adanya piutang tak tertagih pada PT. BPR Prima Mulia Anugrah Cabang Padang.

Penyimpangan dalam pelaksanaan prosedur pemberian kredit dapat menimbulkan niat buruk nasabah untuk tidak melunasi kewajibannya dengan anggapan resiko yang ditanggungnya kecil. Seperti penyimpangan dalam kelengkapan berkas-berkas kredit atau tidak memperhatikan prinsip-prinsip dalam pemberian kredit. Pihak bank tidak memiliki informasi yang lengkap tentang debitur, sehingga pihak bank tidak mengetahui adanya resiko yang akan ditanggung jika ternyata debitur tersebut memiliki sifat buruk atau curang dalam kredit.

Penelitian Veralita \& Khairani (2014) tentang faktor-faktor mempengaruhi penyebab piutang tak tertagih pada Koperasi Baitul Malwat Tamwil (BMT) Tarbiyah Palembang mendukung hasil penelitian ini bahwa penyimpangan dalam pelaksanaan prosedur pemberian kredit berpengaruh positif terhadap piutang tak tertagih.

\section{Pengujian terhadap variabel penerapan kebijakan pemerintah}

Hasil pengujian variabel penerapan kebijakan pemerintah pada penelitian ini menunjukkan pengaruh positif dan signifikan terhadap piutang tak tertagih. Kofesien regresinya sebesar 0,570 dan hasil uji $\mathrm{T}$ menunjukkan nilai signifikan sebesar $0,000<0,05$. Dapat disimpulkan bahwa variabel penerapan kebijakan pemerintah berpengaruh terhadap adanya piutang tak tertagih pada PT. BPR Prima Mulia Anugrah Cabang Padang.

Kebijakan pemerintah tentang bunga kredit, pajak dan tarif listrik serta kebijakan lainnya seperti kenaikan harga Bahan Bakar Minyak (BBM), merupakan yang sering dijadikan alasan oleh debitur yang tidak menbayar hutangnya dengan anggapan bahwa tingkat suku bunga kredit yang tinggi sehingga tidak sanggup untuk melunasi hutang, tarif pajak yang tinggi sehingga mengurangi pendapatannya atau kenaikan tarif listrik yang membuat penghasilan dari usahanya menurun.

Hasil penelitian ini didukung oleh penelitian sebelumnya yang dilakukan Lutfi Arrum Sari (2015) menunjukkan bahwa faktor-faktor yang menjadi penyebab piutang tak tertagih pada PT. PELINDO III Cabang Tanjung Emas Semarang yaitu berasal dari pihak internal dan pihak eksternal. Kebijakan pemerintah merupakan faktor yang menyebabkan piutang tak tertagih yang ditimbulkan oleh pihak eksternal.

Penelitian Algumeri (2013) mendukung bahwa kebijakan pemerintah, bencana alam, penyimpangan pemberian kredit, pendapatan dan pengeluaran pemanfaat yang tidak menentu, itikad baik nasabah dan penyalahgunaan dana yang telah diberikan menjadi faktor penyebab terjadinya kredit macet. penelitian Yulianto (2011) juga mendukung bahwa faktor eksternal (kebijakan pemerintah dan perkembangan teknologi) memiliki pengaruh positif terhadap kedit macet.

\section{SIMPULAN} berikut :

Dari hasil dan pembahasan diatas, maka diambil kesimpulan sebagai 
1. Berdasarkan hasil pengujian, koefisien regresi variabel penyimpangan dalam pelaksanaan prosedur pemberian kredit sebesar 0,396 dan hasil uji $\mathrm{T}$ menunjukkan nilai signifikan sebesar 0,019>0,05. Hal ini menunjukkan variabel penyimpangan dalam pelaksanaan prosedur pemberian kredit berpengaruh positif signifikan terhadap piutang tak tertagih pada PT. BPR PMA Cabang Padang dan disimpulkan bahwa H1 diterima.

2. Berdasarkan hasil pengujian variabel penerapan kebijakan pemerintah menunjukkan pengaruh positif signifikan terhadap piutang tak tertagih. Koefisien regresinya sebesar 0,570 dan hasil uji $\mathrm{T}$ menunjukkan nilai signifikan sebesar 0,000<0,05. Dapat disimpulkan bahwa H2 Diterima karena variabel penerapan kebijakan pemerintah berpengaruh positif signifikan terhadap piutang tak tertagih pada PT. BPR PMA Cabang Padang.

\section{UCAPAN TERIMA KASIH}

Dengan terselesaikannya karya ilmiah ini, penulis mengucapkan terima kasih yang sedalam-dalamnya kepada :

1. Allah S.W.T atas limpahan karunia dan hidayahnya sehingga penulis dapat melaksanakan penelitian dan menyelesaikan karya ilmiah.

2. Bapak Febriyandhie Ananda, SE.MM selaku Ketua Sekolah Tinggi Ilmu Ekonomi-Keuangan Perbankan dan Pembangunan (STIE-KBP) Padang.

3. Ibu Dewi Zulvia, SE.MM, selaku Ketua Program Studi Jurusan Akuntansi di STIE-KBP Padang.

4. Bapak Renil Septiano, SE.MM, selaku Dosen Pembimbing dalam penyusunan Skripsi yang selalu mengingatkan, memberikan arahan dan dukungan sehingga penulis dapat menyelesaikannya dengan baik.

5. Ibu Lisa Amelia Herman, SE.MM, selaku Dosen Pembimbing Akademik Jurusan Akuntansi di STIE-KBP Padang.

6. Bapak Ade Chandra, A.md selaku pimpinan cabang PT. BPR Prima Mulia Anugrah Cabang Padang yang telah memberikan izin penelitian di Bank tersebut.

\section{DAFTAR PUSTAKA}

Ainni, A. (2010). Perilaku Menyimpang. Retrieved from https://sarianggrainni.wordpress.com/2010/11/29/12/amp/

Alfi Yunita, G. (2016). Peran Kebijakan Pemerintah Dalam Pemberian Kredit Usaha Rakyat Pada Usaha Mikro Kecil dan Menengah (UMKM).

Algumeri, M. (2013). Analisis Faktor Penyebab Kredit Macet Pada Bumdes Mitra Bersama Desa Bengkolan Salak, 1-11.

Asmawati. (2011). Prosedur Pemberian Kredit Konsumtif Pada PD. BPR Rokan Hilir.

Cawidu, R. A., \& Cangara, H. (2011). Kebijakan Pemerintah Republik Indonesia Dalam Mengatasi Situs Porno Pada Media Maya, 1, 1-13.

Haninun. (2011). Pengaruh Pengendalian Intern Perkreditan Terhadap Kredit Bermasalah Pada PT.BANK RAKYAT INDONESIA(PERSERO) Tbk, Cabang Teluk Betung, 2(1). 
Kurniawan Syaputera, E., \& Khairani, S. (2013). Analisis Piutang Tak Tertagih Pada PT . Bima Finanace Palembang, 1-9.

Lutfi Arrum Sari, A. (2015). Analisis Faktor-Faktor Penyebab Piutang Tak Tertagih Pada Pt.Pelindo Iii (Persero) Cabang Tanjung Emas Semarang. Universitas Negeri Semarang.

Muslim. (2012). Analisis Faktor-Faktor Yang Mempengaruhi Kredit Macet (Kurang Lancar, Diragukan Dan Macet) Pada UMKM Industri Mebel Di Kabupaten Jepara Tahun2012.

Sugiartono, E. (2013). Inflasi dan Kebijakan Pemerintah. Retrieved from edisugiartonos.blogspot.co.id/2013/05/inflasi-dan-kebijakanpemerintah.html? $\mathrm{m}=1$

Veralita, M., \& Khairani, S. (2014). Faktor Faktor Mempengaruhi Penyebab Piutang Tak Tertagih Pada Koperasi Baitul Malwat Tamwil (BMT) Tarbiyah Palembang, 1-15.

Yulianto, A. (2011). Faktor Internal-Eksternal Yang Mempengaruhi Kredit Macet Pada Nasabah Pd. BPR BKK Wonosobo. 